\title{
The anti-TNF- $\alpha$ antibody infliximab indirectly regulates PECAM-1 gene expression in two models of in vitro blood cell activation
}

\author{
Federico Moriconi*, Ihtzaz Ahmed Malik*, Ahmad Amanzada, Martina Blaschke, Dirk Raddatz, Sajjad Khan \\ and Giuliano Ramadori
}

Chronic inflammatory bowel diseases can be successfully treated with antibodies against the acute phase mediator TNF- $\alpha$. The process of activation and of extravasation of inflammatory cells from the blood into the 'stressed' tissue site is controlled by cytokines and chemokines, which attract leukocytes and by adhesion molecules, which mediate their attachment and transmigration toward the affected cell(s). The changes in the gene expression of adhesion molecules taking place in those cells before attachment have been less investigated. Changes of PECAM-1, ICAM-1 and vascular cell adhesion molecule-1 (VCAM-1) gene expression were studied in phytohaemagglutinin (PHA)- and lipolysaccharide (LPS)-treated human peripheral blood leukocytes (PBLs), granulocytes and the human monocyte cell line U-937. Cells were treated either with PHA or with LPS in the presence or absence of infliximab and incubated with TNF- $\alpha$, IFN- $\gamma$ and/or transforming growth factor beta (TGF- $\beta$ ) and treated as above. Activation of PBLs by PHA or LPS treatment triggered a sharp upregulation of ICAM-1, VCAM-1 gene expression and a time-dependent downregulation of PECAM-1 gene expression reaching a minimum $4 \mathrm{~h}$ from start of the experiment. The anti-TNF- $\alpha$ antibody infliximab, by neutralizing TNF- $\alpha$ and IFN- $\gamma$ production, completely reversed PECAM-1 mRNA downregulation and ICAM- 1 and VCAM-1 upregulation. Immunostaining of PBLs cytospins with antibodies against PECAM-1 and ICAM-1 confirmed RT-PCR and western blot results. PBLs IFN- $\gamma$ or TNF- $\alpha$ treatment downregulated PECAM- 1 in parallel with the upregulation of ICAM-1 and VCAM-1 gene expression, whereas TGF- $\beta$ upregulated PECAM-1- and downregulated ICAM-1 and VCAM-1 gene expression counteracting the effect of TNF- $\alpha$ or IFN- $\gamma$. Similar results were obtained in human U937 cells and in granulocyte cultures by TNF- $\alpha$ or IFN- $\gamma$ treatment. Taken together, these results suggest that infliximab, blocking TNF- $\alpha$ and IFN- $\gamma$ production, exerts its anti-inflammatory effect through inhibiting downregulation of PECAM-1 gene expression and upregulation of ICAM-1 and VCAM-1 expression in leukocytes of the peripheral blood. These results also suggest that TGF- $\beta$ may thus be of therapeutic importance as an anti-inflammatory agent.

Laboratory Investigation (2012) 92, 166-177; doi:10.1038/labinvest.2011.160; published online 31 October 2011

KEYWORDS: adhesion molecules; cytokines; granulocytes; inflammatory bowel disease; infliximab; peripheral blood leukocytes

Impaired intestinal immunoregulation has a central role in the pathogenesis of chronic inflammatory bowel diseases (IBDs) such as ulcerative colitis (UC) and Crohn's disease (CD). ${ }^{1}$ Acute flares in IBDs are characterized by an excessive recruitment of leukocytes from the blood circulation into the inflamed gut wall.
Neutrophils are the first line of immune defense ${ }^{2,3}$ as they are recruited from the blood to sites of injury where they contribute to destruction of the initiating noxae and damaged tissue. ${ }^{4}$ During acute flares of UC or CD there is a massive infiltration of neutrophil granulocytes into the affected mucosa, which is manifested clinically by an increase

Department of Internal Medicine, Division of Gastroenterology and Endocrinology, University Hospital, Georg-August University Göttingen, Göttingen, Germany Correspondence: Professor Dr G Ramadori, MD, Department of Internal Medicine, Division of Gastroenterology and Endocrinology, University Hospital, Georg-AugustUniversity Göttingen, Robert-Koch-Street 40, 37075 Göttingen, Germany.

E-mail: gramado@med.uni-goettingen.de

*These authors contributed equally to this work.

Received 28 May 2011; revised 19 August 2011; accepted 21 September 2011 
in stool granulocytes. Furthermore, lactoferrin, a major component of the secondary granules of neutrophils, is increased in stool and has been shown to correlate with colonoscopic grading systems in patients with IBDs. ${ }^{5}$

In IBDs there is also a marked infiltration of macrophages into the affected mucosa, manifested by an increase in macrophage-derived inflammatory cytokines IL- $1 \beta$, IL- 6 and TNF- $\alpha$ during acute flares. ${ }^{6}$

In vitro 'activation' of peripheral blood leukocytes (PBLs) is an established model system that mimics acute (and chronic) inflammation. ${ }^{7}$ As such it has been used to define the disease-related profiles occurring in patients affected by various disorders. ${ }^{8-10}$ Importantly the PBLs model faithfully mimics the phenomena observed in inflamed tissues. ${ }^{11}$

Infliximab is a chimeric monoclonal antibody specific for TNF- $\alpha$ having a murine variable region and a human immunoglobulin constant region. It has been shown to have efficacy against $\mathrm{CD}$, rheumatoid arthritis, psoriasis and ankylosing spondylitis. ${ }^{12}$ Treatment with infliximab strongly reduces inflammation in $\mathrm{CD}^{13}$ limiting TNF- $\alpha$ and IFN- $\gamma$ mRNA levels in colorectal mucosa obtained from patients with UC. ${ }^{14}$ Several different mechanisms have been proposed to explain the actions of infliximab. It neutralizes TNF- $\alpha,{ }^{15}$ and induces apoptosis of activated T cells and lymphocytes in the lamina propria thereby reducing the levels of IL-1, IL-6, IL-18 and IFN- $\gamma$ both in vivo ${ }^{16-18}$ and in vitro. ${ }^{19-21}$

In the present investigation we determined the changes in the levels and gene expression of the adhesion molecules PECAM-1, ICAM-1 and vascular cell adhesion molecule-1 (VCAM)-1 in two different in vitro models of inflammation, phytohaemagglutinin (PHA)- and LPS-stimulated PBLs, and we defined which adhesion molecules are restored by infliximab treatment in activated leukocytes. In addition, the expression profiles of the genes encoding human PECAM-1 and ICAM-1 in a promonocytic cell line U-937 (a model used to study macrophages biological functions) in response to treatment with PHA and LPS have been defined and using these two models the effect of the anti-TNF- $\alpha$ antibody, infliximab, on PECAM-1, ICAM-1 and VCAM-1 gene expression was determined.

The results of this investigation show that the activation of PBLs and monocytes by PHA or LPS treatment induces a sharp upregulation of ICAM-1 and VCAM-1 gene expression and a time-dependent downregulation of PECAM-1 gene expression.

As TNF- $\alpha$ and IFN- $\gamma$ downregulate PECAM-1 gene expression in liver sinusoidal endothelial cells and in rat liver macrophages in parallel with ICAM-1 upregulation ${ }^{22,23}$ and both cytokines are inhibited by infliximab, ${ }^{19}$ the identity of the cytokines responsible for PECAM-1 downregulation in activated PBLs and in granulocytes was investigated.

The anti-TNF- $\alpha$ antibody infliximab, by neutralizing TNF- $\alpha$ and inhibiting IFN- $\gamma$ gene synthesis, prevents
PECAM-1 mRNA downregulation as well as ICAM-1 and VCAM-1 upregulation.

Based upon these data it can be concluded that the anti-TNF- $\alpha$ antibody indirectly regulates PECAM- 1 gene expression through IFN- $\gamma$ downregulation whereas TNF- $\alpha$ treatment increases IFN $-\gamma$ gene expression. Transforming growth factor beta (TGF- $\beta$ ) may exert an anti-inflammatory effect inducing PECAM-1 expression and re-establishing endothelial barrier integrity.

\section{MATERIALS AND METHODS \\ Isolation and Culture Conditions of Human PBLs and Promonocytic Cell Line U-937}

Human PBLs were isolated from five healthy blood donors by Ficoll density gradient centrifugation and dextran sedimentation according to Bøyum. ${ }^{24}$ Residual red blood cells were hypotonically lysed. Subsequently PBLs were washed three times with phosphate-buffered saline (PBS), pH 7.3. PBLs $\left(1 \times 10^{6}\right)$ were cultured in $1 \mathrm{ml}$ medium (RPMI 1640 with L-glutamine, $10 \%$ fetal calf serum, $10000 \mathrm{U} / \mathrm{ml}$ penicillin and $10000 \mathrm{mg} / \mathrm{ml}$ streptomycin (Bio Whittaker, Verviers, Belgium)) and stimulated in vitro with PHA $(5 \mu \mathrm{g} / \mathrm{ml})$ (Roche Molecular Biochemicals, Mannheim, Germany) or LPS $(1 \mu \mathrm{g} / \mathrm{ml})$ (Sigma-Aldrich Chemie, Taufkirchen, Germany) in the absence or presence of the antibody against human TNF- $\alpha$ infliximab (Remicade, $1000 \mu \mathrm{g} / \mathrm{ml}$; MSD, München, Germany) for different lengths of time. Although in preliminary experiments some effects were observed with lower concentrations, the dose of $1000 \mu \mathrm{g} / \mathrm{ml}$ allowed us to obtain reproducible and significant effects without any sign of cytotoxicity.

In a second set of experiments, PBLs were stimulated with either human IFN- $\gamma$ (500 U/ml) (Roche, Germany), TGF- $\beta$ $(5 \mathrm{ng} / \mathrm{ml})$ (PeproTech, Hamburg, Germany) or TNF- $\alpha$ $(10 \mathrm{ng} / \mathrm{ml})$ (Roche) in the presence or absence of TGF- $\beta$.

U937 promonocytic cells were seeded at $2 \times 10^{5} \mathrm{cells} / \mathrm{ml}$ in RPMI 1640 medium containing 10\% (v/v) heat-inactivated fetal calf serum, $2 \mathrm{mM} / \mathrm{l}$ L-glutamine, $1 \mathrm{mM} / \mathrm{l}$ sodium pyruvate and $1 \mathrm{mM}$ of non-essential amino acids, and cultured at $37^{\circ} \mathrm{C}$ in an atmosphere of $95 \%$ air, $5 \% \mathrm{CO}$. They were then stimulated in vitro with PHA $(5 \mu \mathrm{g} / \mathrm{ml})$ or LPS $(1 \mu \mathrm{g} / \mathrm{ml})$ for different lengths of time.

Isolation of Human Granulocytes and Culture Conditions Human granulocytes were isolated from the heparinized peripheral blood of healthy donors $(n=3)$ using the Histopaque-1077 and Histopaque-1119 gradient density centrifugation (Sigma-Aldrich, USA). Residual erythrocytes were removed by washing with an erythrocyte lysis buffer and monocytes by cell incubation in a culture flask with RPMI medium for $30 \mathrm{~min}$ at $37^{\circ} \mathrm{C}$. The non adherent cells were washed three times, counted, resuspended in cold PBS at $1 \times 10^{6}$ cells $/ \mathrm{ml}$ and treated with PHA or LPS as described for PBLs. Granulocytes cultures were stimulated and processed 
as described for PBLs in the presence or absence of infliximab. In a separated set of experiments, granulocytes were alternatively treated with TNF- $\alpha(10 \mathrm{ng} / \mathrm{ml})$ or with IFN- $\gamma(500 \mathrm{U} / \mathrm{ml})$.

\section{RNA Isolation, Quantitative Real-time RT-PCR}

Isolation of total cellular RNA from human PBLs and from granulocytes was performed according to the RNeasy Mini Protocol with the RNeasy total RNA extraction Mini Kit (QIAGEN, Hilden, Germany). The isolated RNA was used for quantitative real-time RT-PCR using the Superscript kit from Invitrogen (Groningen, Netherlands) following the manufacturer's instructions. Real-time PCR analysis of cDNA was performed at $60^{\circ} \mathrm{C}$ to $95^{\circ} \mathrm{C}$ for 45 cycles in the Sequence Detection System of ABI Prism 7000 (Applied Biosystems, Darmstadt, Germany) following the manufacturer's instructions and by using SYBR Green Reaction Master Mix (ABI Prism; Applied Biosystems) and the primers listed in Table 1. All primers were synthesized by Invitrogen. In every RNA sample, $\beta$-actin mRNA was measured as the housekeeping gene. $\beta$-actin was chosen as housekeeping gene in according to the experience obtained in previous experiments as the gene expression (Ct values) was constant in different experimental settings.

Values were then compared with those obtained by using the control-RNA obtained from unstimulated cells. The results were normalized to the housekeeping gene and fold change expression was calculated using threshold cycle $(\mathrm{Ct})$ values. During a real-time RT-PCR, the Ct value is known as the number of cycles when the expression of any specific gene under study reaches a predetermined threshold of detection defined as the fractional cycle number at which the fluorescence passes the fixed threshold. The higher the $\mathrm{Ct}$ value is for a specific gene at a given time, the lower the amount of specific mRNA is in the preparation. For calculation of the relative changes, gene expression measured in unstimulated cells at $0 \mathrm{~h}$ was set at 1 .

Table 1 Sequence of human gene-specific primers used for quantitative RT-PCR analysis

\begin{tabular}{|c|c|c|}
\hline Primer & Forward $5^{\prime} \rightarrow 3^{\prime}$ & Reverse $5^{\prime} \rightarrow 3^{\prime}$ \\
\hline PECAM-1 & CCAGTGTCCCCAGAAGCAAA & TGATAACCACTGCAATAAGTCCTITC \\
\hline AM-1 & GCAGACAGTGACCATCTACAGCTT & CTTCTGAGACCTCTGGCTTCGT \\
\hline VCAM-1 & GGCAGGCTGTAAAAGAATTGCA & GTCATGGTCACAGAGCCACCTT \\
\hline IFN- $\gamma$ & CCAACGCAAAGCAATACATGA & TITCGCTTCCCTGTITAGCT \\
\hline TNF- $\alpha$ & CCCAGGCAGTCAGATCATCTTC & AGCTGCCCCTCAGCTTGA \\
\hline TGF- $\beta$ & GGGAACACCACCACTCTCATTAG & CAAATTACCACTCGGAAGTTCGT \\
\hline IL-6 & TGGCTGAAAAAGATGGATGCT & AACTCCAAAAGACCAGTGATGATT \\
\hline$\beta$-actin & CTGGCACCCAGCACAATG & CCGATCCACACGGAGTACTTG \\
\hline
\end{tabular}

\section{Antibodies}

Rabbit polyclonal antibody directed against human ICAM-1 was purchased from Abcam (Cambridge, UK, catalog no. ABIN343417). Mouse monoclonal antibody directed against human PECAM-1 was purchased from Dako (Hamburg, Germany, catalog no. M0823). The CD-31 mouse monoclonal antibody (clone JC70A) recognizes formalinresistant $130 \mathrm{kDa}$ glycoprotein epitope on extracellular domain 1. The anti-PECAM-1 and anti-ICAM-1 antibodies were used for the double immunofluorescence staining studies. ${ }^{25}$

\section{Cytospin Preparation, Immunofluorescent Staining and Immunocytology}

PBLs and neutrophil granulocytes were placed on poly-Llysine-coated microscope slides using cytocentrifugation (5 min at $500 \mathrm{rpm}$ ). In all, 100000 cells/cytospin were fixed at room temperature using cold methanol solution, followed by $10 \mathrm{~s}$ in cold acetone solution and air dried. After washing in distilled water, endogenous peroxidase activity was blocked by incubating the slides in 3\% hydrogen peroxide solution in methanol for $5 \mathrm{~min}$ followed by a wash in $10 \mathrm{mM}$ PBS $(\mathrm{pH}=7.5)$. The cytospin preparations were treated with universal blocking serum (Novocastain Super ABC Kit, Novocastra Laboratories, Newcastle upon Tyne, UK) for $20 \mathrm{~min}$ at room temperature. The single- and doubleimmunofluorescence studies were performed according to a protocol described previously ${ }^{26}$ with the rabbit polyclonal antibody against ICAM-1 and the mouse monoclonal anti-PECAM-1 (1:50), were incubated with the cytospins overnight at $4^{\circ} \mathrm{C}$. Following a short washing step in PBS, incubation was carried out with Alexa-Fluor-conjugated goat anti-rabbit and anti-mouse secondary antibody (1:200; Molecular Probes, Germany) at room temperature for $1 \mathrm{~h}$. The sections were then washed three times for $5 \mathrm{~min}$ in PBS. Finally, cell nuclei were stained with 4',6-diamidino-2phenylindole, and the sections were washed and mounted. The number of positive PECAM-1 cells after PBLs incubation with PHA or LPS was counted for 100 cells from 10 different areas of each slide. PECAM-1 APAAP immunostaining of human PBLs was performed as described. ${ }^{27}$ Negative controls were produced by replacing the primary antibody with murine IgGs.

\section{Protein Extraction and Western Blot Analysis from Human PBLs, Neutrophil Granulocytes and Human Monocyte Cells}

Cells (PBLs, neutrophil granulocytes and U-937 cell line) were lysed in $50 \mathrm{mM}$ HEPES, $150 \mathrm{mM} \mathrm{NaCl}, 1 \mathrm{mM}$ EDTA, $1 \mathrm{mM}$ EGTA, $10 \%$ glycerol, $1 \%$ Triton X-100, $1 \mathrm{mM}$ phenylmethylsulfonyl fluoride, $1 \mathrm{~g} / \mathrm{ml}$ aprotinin, $0.5 \mathrm{mM}$ sodium orthovanadate and $20 \mathrm{mM}$ sodium pyrophosphate. Lysates were centrifugated at $14000 \times \mathrm{rpm}$ for $10 \mathrm{~min}$. The protein content of the cellular lysates was calculated by the Coomassie Protein Assay (Pierce, Germany) in which $\beta$-actin 
was used as the loading control. Proteins were transferred onto Hybond-ECL nitrocellulose hybridization transfer membranes according to Towbin et l. $^{28}$ The immunodetection studies were performed according to the ECL western blotting protocol of GE Healthcare (Germany). The primary rabbit polyclonal antibody to ICAM-1 was used at 1:250 dilution, whereas the mouse monoclonal antiPECAM-1 was used at a 1:500 dilution and the anti-rabbit and anti-mouse immunoglobulins were each used at a 1:2000 dilution.

\section{Statistical Analysis}

The data were analyzed with Prism Graph Pad 4 software (San Diego, USA). All experimental errors are shown as SEM. Statistical significance was calculated by Student's $t$-test, one-way analysis of variance and Dunnett's post hoc tests. Significance was accepted at $P<0.05$.

\section{RESULTS}

Changes of ICAM-1, PECAM-1 and VCAM-1 Gene Expression In Vitro PHA- and LPS-Activated Human PBLs

In according to the experience obtained in previous experiments, we used $\beta$-actin as a housekeeping gene because its $\mathrm{Ct}$ values were constant and did not change in different experimental setting using real-time PCR (data not shown).

PHA treatment induced a time-dependent downregulation of PECAM-1 mRNA, reaching a minimum value within $8 \mathrm{~h}$ (20-fold downregulation). LPS treatment produced the same effect but achieved a nadir of 10 -fold reduction after $4 \mathrm{~h}$ of treatment (Figure 1a).

In contrast to PECAM-1 downregulation, ICAM-1 and VCAM-1 gene expression were sharply increased by PHA
(18 \pm 1.8 -fold, $\quad 10 \pm 0.03$-fold $)$ and LPS (11.7 \pm 1 -fold, $10 \pm 0.02$-fold) reaching a peak within $4 \mathrm{~h}$ (Figure $1 \mathrm{~b}$ and $\mathrm{c}$ ). It is noteworthy, that the increase in ICAM-1 and VCAM-1, and the reduction of PECAM-1 occurred as early as $1 \mathrm{~h}$ (Figure 1a-c) suggesting that the regulation of the three genes occurs just after cell stimulation and parallels the sharp upregulation of IFN- $\gamma$ and TNF- $\alpha$ (data not shown). However it is noteworthy, that the amount of VCAM-1 (average of Ct value obtained from real-time $\mathrm{PCR}=31$ ) transcripts in unstimulated and in stimulated-PBLs is much lower than that of ICAM-1 (average of Ct value $=22$ ).

TNF- $\alpha$ stimulated IFN- $\gamma$ gene expression with a maximum effect seen at $8 \mathrm{~h}(21 \pm 3$-fold, Figure 2a). LPS and, at a lower dose, IFN- $\gamma$ induced a strong upregulation of TNF- $\alpha$ gene expression within $4 \mathrm{~h}(68 \pm 10$-and $30 \pm 4$-fold, respectively, Figure $2 \mathrm{~b}$ ). LPS induced IL-6 gene expression within $4 \mathrm{~h}$ (16-fold compared with unstimulated cells, Figure 2c). In order of magnitude, TGF- $\beta$ (four-fold), IFN- $\gamma$ (two-fold) and TNF- $\alpha$ (two-fold) upregulated IL-6 gene expression (Figure 2c). PBLs treatment with LPS, TNF- $\alpha$ or IFN- $\gamma$ induced a downregulation of the TGF- $\beta$ mRNA (Figure $2 \mathrm{~d}$ ).

\section{Changes of ICAM-1, PECAM-1, VCAM-1 Gene Expression in Activated Human PBLs Induced by the anti-TNF- $\alpha$ Antibody Infliximab}

As PECAM-1 and ICAM-1 are implicated in the regulation of inflammatory responses, the question arose can an immunosuppressant influence gene regulation of these adhesion molecules. In response to treatment of stimulated PBLs with anti-TNF- $\alpha$ antibody infliximab the prior PHA- and LPSinduced PECAM-1 downregulation was abated (Figure 1a).
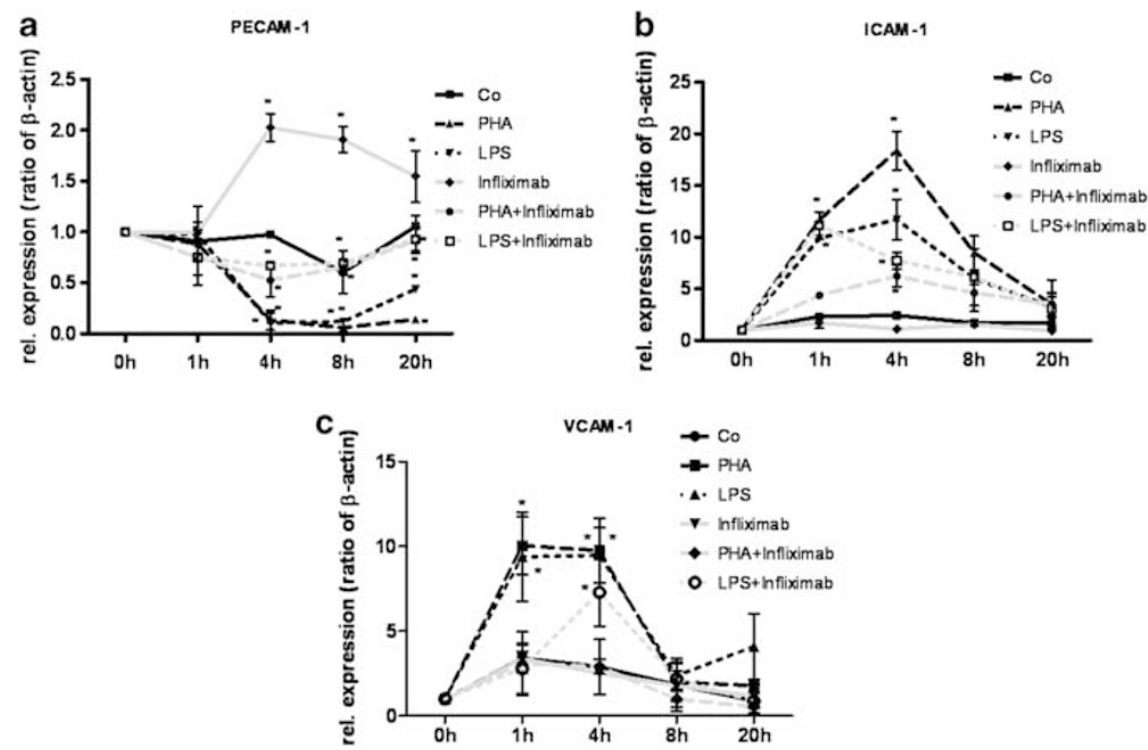

Figure 1 Quantification of mRNA expression of PECAM-1 (a), ICAM-1 (b) and VCAM-1 (c) in PBLs stimulated with infliximab in the presence or absence of PHA and LPS. RT-PCR data were shown as fold changes in mRNA expression normalized with the housekeeping gene $\beta$-actin. Results represent the mean value \pm s.e.m. of five separate experiments $\left({ }^{*} P<0.05 ; n=5\right)$. 

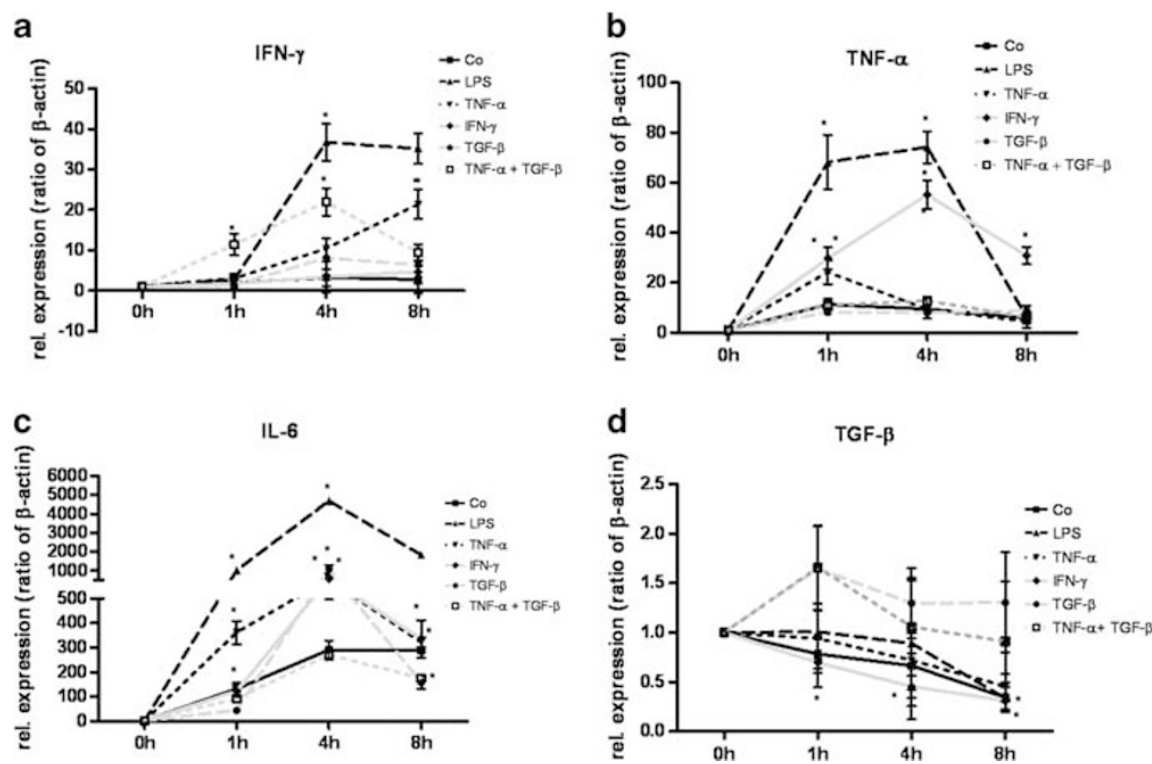

Figure 2 Fold change of mRNA expression of IFN- $\gamma(\mathbf{a})$, TNF- $\alpha(\mathbf{b})$, IL-6 (c) and TGF- $\beta$ (d) at different time points in in vitro activated human PBLs related to unstimulated cells and after treatment with the cytokines TNF- $\alpha$, IFN- $\gamma$, TGF- $\beta$, TNF- $\alpha$ and TGF- $\beta$. RT-PCR data, shown as fold changes in mRNA expression normalized with the housekeeping gene $\beta$-actin. Results represent the mean value \pm s.e.m. of five separate experiments $\left({ }^{\star} P<0.05\right.$ ).

Furthermore, the anti-TNF- $\alpha$ antibody suppressed PHAmediated ICAM-1 induction of gene expression (from $11.6 \pm 0.08$ - to $4.3 \pm 0.1$-fold at $1 \mathrm{~h}$, from $18.3 \pm 1.8$ - to $6.2 \pm 1$-fold at $4 \mathrm{~h}$ and from $8.5 \pm 0.6-$ to $4.5 \pm 1.7$-fold at $8 \mathrm{~h}$, Figure 1b) as well as LPS-mediated ICAM-1 upregulation (from $11.7 \pm 1.9$ - to $7.7 \pm 0.9$-fold). Infliximab had the same inhibitory effect on PHA or LPS-induced upregulation of VCAM-1 gene expression. In fact, it totally suppressed PHAand LPS effect at $1 \mathrm{~h}$ (from 10- to 3-fold and from 9.5- to 2.5 -fold, respectively, Figure 1c).

Changes in Gene Expression of the Adhesion Molecules ICAM-1, PECAM-1, VCAM-1 and of the Pro-inflammatory Cytokines TNF- $\alpha$, IFN- $\gamma$, TGF- $\beta$ and IL- 6 in CytokineStimulated Human PBLs and Neutrophil Granulocytes

To characterize the response of human PBLs to inflammatory conditions, gene expression profiles of isolated PBLs, which were stimulated for 1,4 and $8 \mathrm{~h}$ by TNF- $\alpha$, IFN- $\gamma$, TGF- $\beta$, TNF- $\alpha$ and TGF- $\beta$ in combination, as well as by PHA or LPS were examined. Stimulated samples were compared with unstimulated samples, which were used as control group.

TGF- $\beta$ was the only stimulus able to induce a timedependent induction of PECAM-1 gene expression with a peak effect occurred at $8 \mathrm{~h}(3 \pm 0.3$-fold, Figure $3 \mathrm{a})$, whereas TNF- $\alpha$ and IFN- $\gamma$ inhibited PECAM- 1 gene expression. Stimulation of PBLs with IFN- $\gamma$ induced a sharp upregulation of ICAM-1 and VCAM- 1 gene expression at 1 and $4 \mathrm{~h}$ after stimulation (37 \pm 3 and $21 \pm 2$-fold, Figure $3 \mathrm{~b}$ and $\mathrm{c}$ ). TNF- $\alpha$ induced ICAM- 1 and VCAM- 1 gene expression ( $13 \pm 3$ - and $21 \pm 2$-fold after $1 \mathrm{~h}$, Figure $3 \mathrm{~b}$ and $\mathrm{c}$ ).

As PBLs represent a 'co-culture' of leukocytes, pure granulocyte populations (with a very scarce presence of mono- cytes $<1 \%$ ) were also studied in the same way as PBLs. Using real-time RT-PCR, no effect on PECAM-1 or ICAM-1 gene expression was detected after treatment with PHA or LPS. The constitutive expression of PECAM-1 in vitro PBLs and granulocytes seems to be similar after analyzing the $\mathrm{Ct}$ values obtained from real-time PCR. On the contrary, a PECAM-1 downregulation and a ICAM-1 upregulation were observed $2 \mathrm{~h}$ after starting treatment with IFN- $\gamma$ or TNF- $\alpha$ (data not shown). Notably, in vitro granulocytes isolation lead to a statistic significant spontaneous upregulation of PECAM-1 gene expression just $2 \mathrm{~h}$ after beginning the treatment.

\section{Changes of ICAM-1 and PECAM-1 Gene Expression in PHA- and LPS-Stimulated Human Monocytic Cells, PBLs and Neutrophil Granulocytes}

Western blot analysis of PECAM-1 and ICAM-1 in human U-937 and PBLs confirmed the results obtained for mRNA from activated PBLs as PECAM- 1 levels decreased $4 \mathrm{~h}$ after U-937 stimulation as compared with the control samples (Figure 4a). At the same time, PHA and LPS induced a progressive time-dependent induction of ICAM-1 protein expression with the maximum value achieved at $4 \mathrm{~h}$. Densitometry analysis for PECAM-1 and ICAM-1 western blots from U-937 cell lysates showed a significant downregulation of PECAM-1 after PHA- and LPS-stimulation. A 47 and 60\% downregulation for PECAM-1 after PHA- and LPS-treatment was observed, whereas PHA and LPS induced respectively a $112 \%$ and $46 \%$ upregulation of ICAM-1 expression (Figure 4b).

Furthermore, western blot analysis of cell lysate from unstimulated and stimulated PBLs, using an antibody 

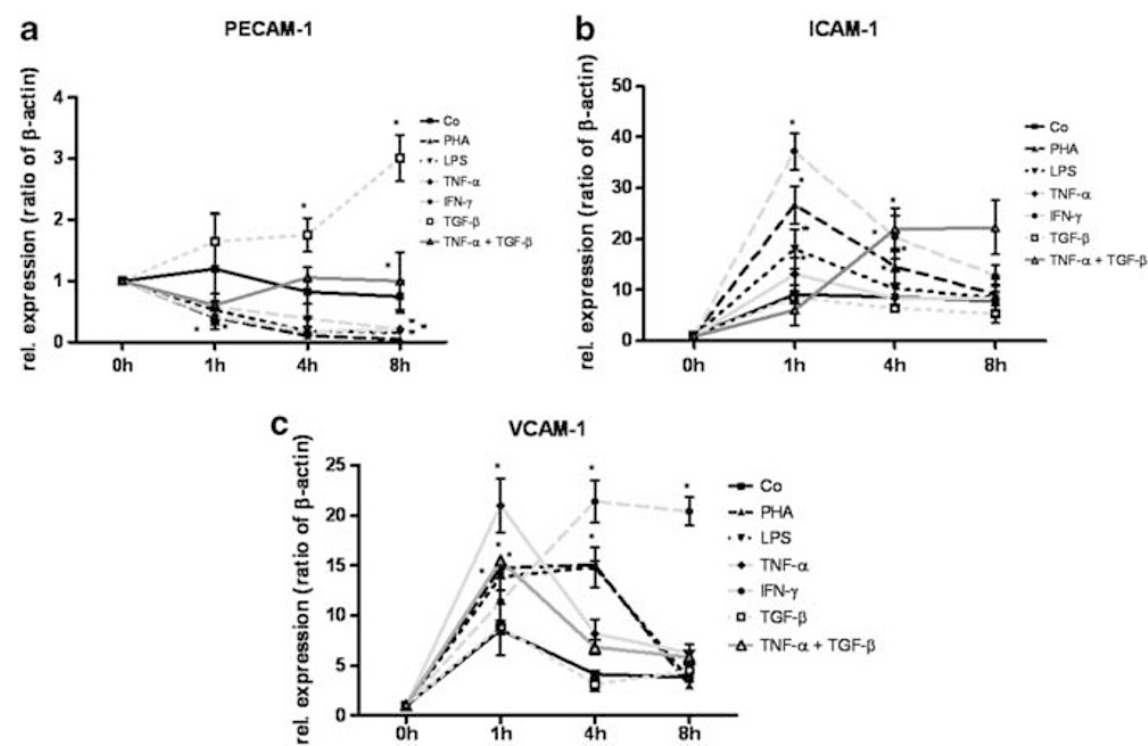

Figure 3 Fold change of mRNA expression of PECAM-1 (a), ICAM-1 (b) and VCAM-1 (c) gene expression at different time points in in vitro activated human PBLs related to unstimulated cells and after treatment with the cytokines TNF- $\alpha$, IFN- $\gamma$, TGF- $\beta$, TNF- $\alpha$ and TGF- $\beta$. RT-PCR data were normalized with the housekeeping gene $\beta$-actin. Results represent the mean value \pm s.e.m. of five separate experiments $\left({ }^{*} P<0.05\right)$.

a

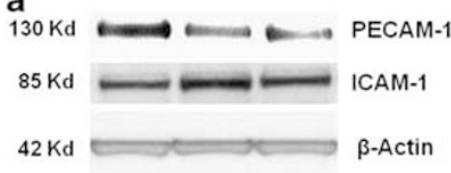

4h CO PHA LPS
C

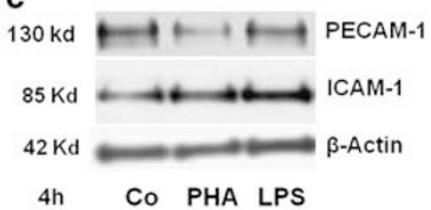

$4 \mathrm{~h}$

d

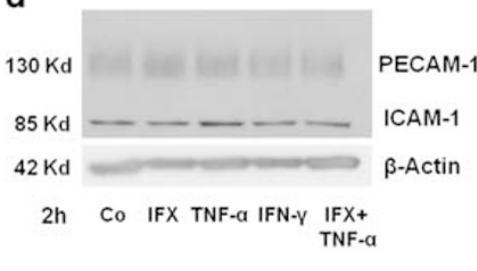

Figure 4 Western blot analysis of cell lysate from unstimulated, PHA- and LPS-stimulated U-937 cell line $4 \mathrm{~h}$ after treatment with antibodies specific for PECAM-1, ICAM-1 and $\beta$-actin, (Co = control) (a). Densitometry analysis of the western blots (b) was performed to show the changes in protein expression of PECAM-1 and ICAM-1. Results represent mean values \pm s.e.m., $\left({ }^{*} P<0.05, n=3\right)$. Western blot analysis of cell lysate from unstimulated, PHA- and LPSstimulated human PBLs $4 \mathrm{~h}$ after treatment using antibody against PECAM-1 and ICAM-1 clearly showed a downregulation of PECAM-1 and an increase in ICAM-1 synthesis after treatment with PHA and LPS compared with unstimulated cells $(n=3, c)$. Western blot analysis of cell lysate from human granulocytes after $2 \mathrm{~h}$ incubation with infliximab (IFX), TNF- $\alpha$, IFN- $\gamma$, infliximab plus TNF- $\alpha$ compared with unstimulated cells $(n=3, \mathbf{d})$.

against PECAM-1 or ICAM-1, clearly showed a downregulation of PECAM-1 and an upregulation of ICAM-1 synthesis after treatment with PHA or LPS compared with unstimulated cells (Figure 4c), confirming real-time PCR results. Western blot analysis of protein lysates from human granulocytes also confirmed real-time PCR results as an induction of ICAM-1 and a suppression of PECAM-1 synthesis after incubation with TNF- $\alpha$ or IFN- $\gamma$ was observed (Figure 4d).

\section{Identification of PECAM-1 ${ }^{+}$in In Vitro Activated Human PBLs by Immunofluorescence Single Staining and by APAAP Immunostaining}

By using a monoclonal antibody directed against PECAM-1/ CD-31, immunoreactivity of PECAM-1 was detectable in unstimulated and activated PBLs confirming the results, obtained at the RNA and protein level with PECAM-1 expression being seen in stimulated and control PBLs (Figure 5). Compared with unstimulated cells, a significant 


\section{PECAM-1}

4h-Control
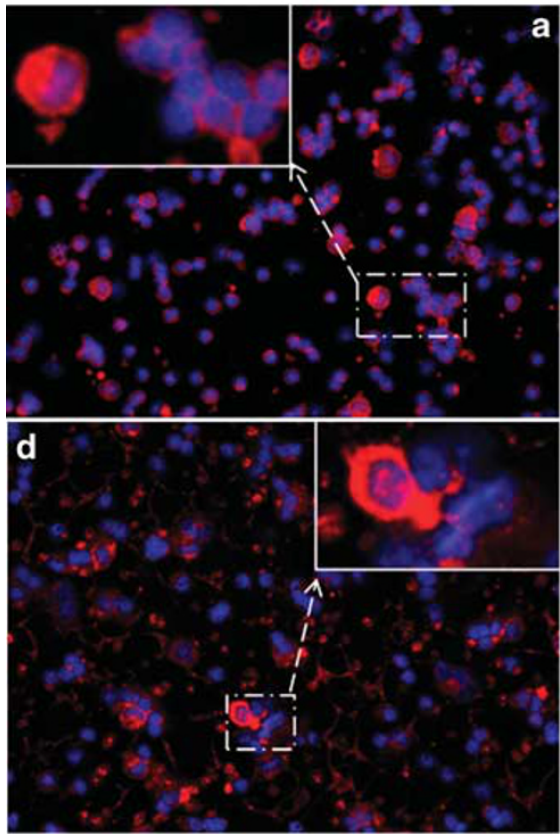

4h-Infliximab
4h-PHA
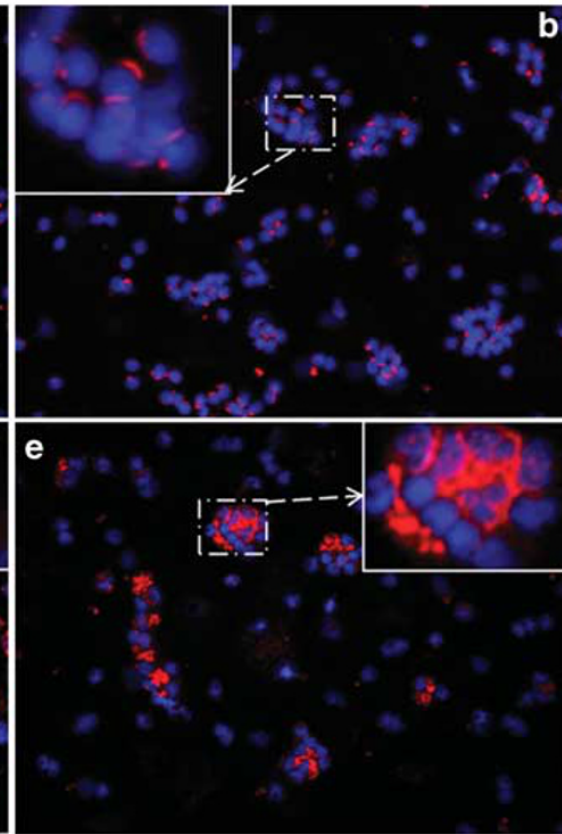

4h-PHA+Infliximab
4h-LPS
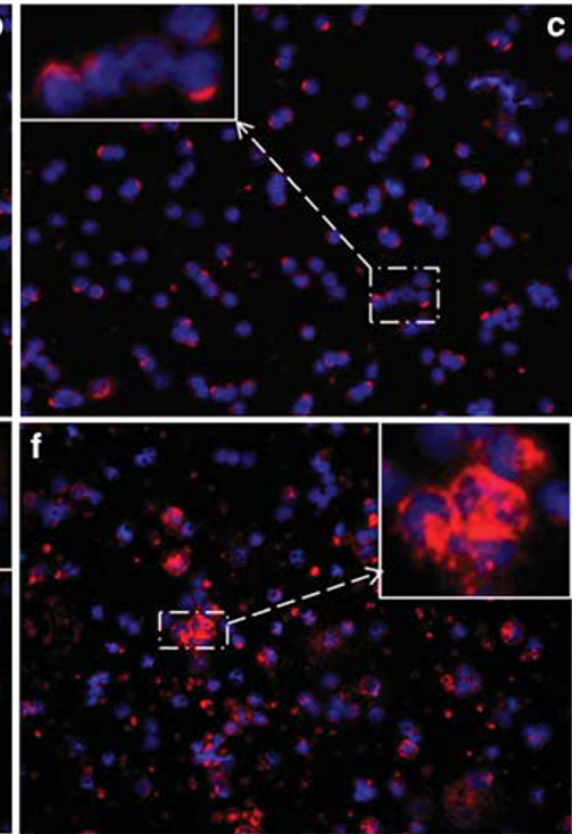

4h-LPS+Infliximab

Figure 5 Immunofluorescence staining of human PBLs cytospins with monoclonal antibody directed against mouse anti-PECAM-1 (red) followed by fluorescence immunodetection in cytospins of unstimulated PBLs (a) and $4 \mathrm{~h}$ after treatment with PHA (b), LPS (c), infliximab (d) alone or in combination with PHA (e) or LPS (f). Original magnification: $\times 200$. Scale bar $=100 \mu \mathrm{m}$.

rapid and progressive reduction of PECAM-1 positivity in PBLs stimulated with PHA or LPS was observed reaching a nadir of inhibition at $4 \mathrm{~h}$, although reduced expression of PECAM-1 was evident already $1 \mathrm{~h}$ after stimulation. After PHA treatment a typical agglutination of PBLs occurred but no numerical reduction was observed. ICAM-1 and VCAM-1 gene expression in the same leukocytes were opposite to those obtained for PECAM-1 and were reduced in the presence of the anti-TNF- $\alpha$ antibody (data not shown).

APAAP immunodetection confirmed the results obtained by immunofluorescence staining as PECAM-1 expression in freshly isolated PBLs (Figure 6), consisting of neutrophil granulocytes and mononuclear cells, were PECAM-1 positive.

\section{In vitro Identification of PECAM-1 ${ }^{+} /$ICAM- $^{+}$Cells in Activated Human PBLs and Neutrophil Granulocytes by Immunofluorescence}

Similar to the results obtained for mRNA and protein, ICAM-1 and PECAM-1 expression was observed in unstimulated PBLs (Figure 7a). After $4 \mathrm{~h}$ of stimulation with PHA or LPS, a reduction in PECAM- ${ }^{+}$cells and an increase in ICAM- $1^{+}$cells (Figure 7b, e) were observed. After counting the PECAM- $1^{+}$cells, we could demonstrate a significant reduction of PECAM- $1^{+}$after PBLs incubation with PHA or LPS. PECAM-1 expression in human PBLs stimulated with the anti-TNF- $\alpha$ antibody infliximab alone or in combination with PHA or LPS was demonstrated (Figure $7 c, d, f$ ).

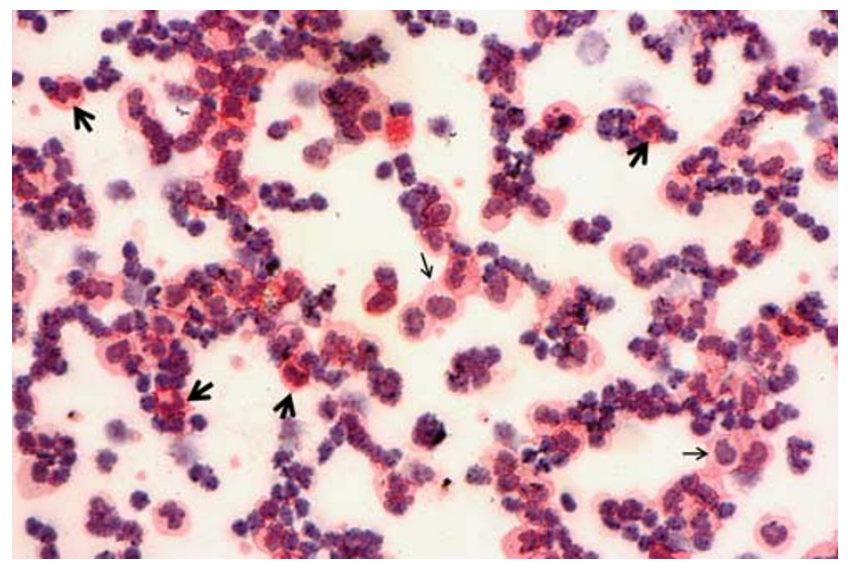

Figure 6 Indirect immunodetection of PECAM-1 in in vitro unstimulated human PBLs using the APAAP method. Cytospins were stained with a mouse monoclonal antibody directed against human PECAM-1 followed by the APAAP immunodetection. The heavy arrows show neutrophil granulocytes but also mononuclear cells (thin arrows), which were PECAM-1 positive. Original magnification: $\times 200$. Scale bar $=100 \mu \mathrm{m}$.

We next asked whether the presence of mononuclear phagocytes is necessary for the induction of the changes of ICAM-1 and PECAM-1 gene expression in granulocytes.

Using antibodies against ICAM-1 and PECAM-1, no significant difference in ICAM- $1^{+}$and PECAM- $1^{+}$granulocytes after treatment with PHA or LPS occurred (data not 

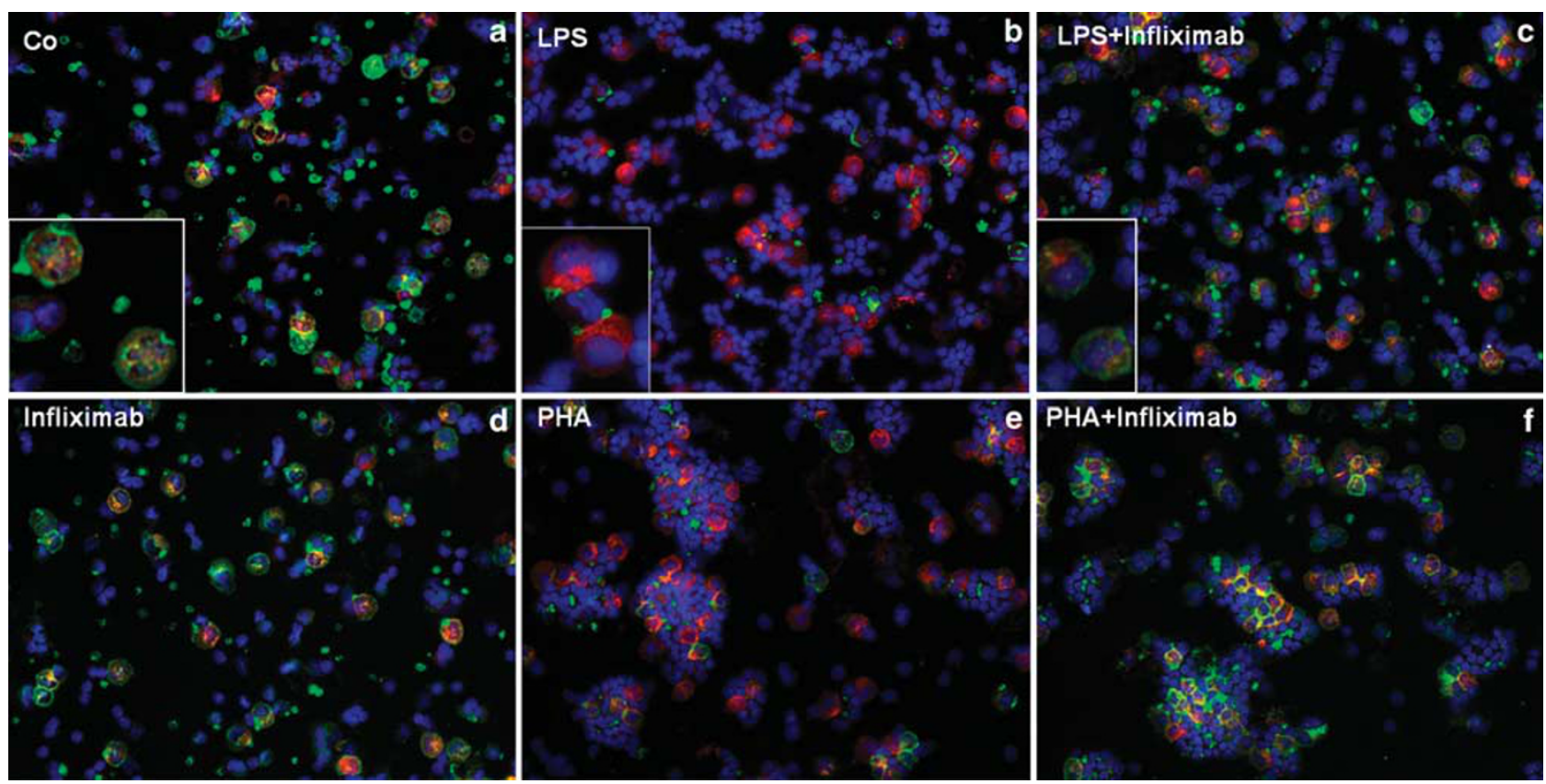

Figure 7 Immunofluorescence double staining of in vitro isolated human PBLs cytospins with monoclonal antibody directed against mouse anti-PECAM-1 (green) and polyclonal antibody against rabbit ICAM-1 (red) followed by fluorescence immunodetection in PBLs unstimulated (a) and stimulated with PHA (e), LPS (b), infliximab alone (d) or in combination with PHA (f) or LPS (c). Original magnification: $\times 200$. Scale bar $=100 \mu$ m.

shown). On the other side, after treating human granulocytes with TNF- $\alpha$, a progressive decrease of PECAM- $1^{+}$cells and an increase of ICAM-1 ${ }^{+}$cells (Figure 8) compared with unstimulated cells was demonstrated by performing separate immunofluorescence single- and double-staining for ICAM-1 and PECAM-1, indicating that the direct interaction of the mononuclear phagocytes with the granulocytes may not be necessary for inducing the observed changes.

It is noteworthy, that PECAM-1 is highly expressed on the cell surface of human PBLs and granulocytes (Figures 5, 7 and 8 ), on the other side ICAM-1 is only barely detectable in control PBLs and granulocytes (Figures 7 and 8).

\section{DISCUSSION}

During the past few years, advances have been made in the understanding of the pathogenesis of IBDs. ${ }^{29}$ IBDs are characterized by continuous recruitment of leukocytes into the inflamed intestine. Neutrophils, as the first line of immune defense, are thought to combat pathogens in concert with mononuclear cells by phagocytosis, degranulation and the release of neutrophil extracellular enzymes. Intestinal macrophages are thought to orchestrate local inflammatory responses ${ }^{30,31}$ They are recruited, probably by activated macrophages, from the blood to sites of injury where they contribute to destruction of the initiating noxae and damaged tissue.

CD and UC are characterized by continuous recruitment of leukocytes into the inflamed intestine after contact with noxious agents. During acute flares of CD or UC there is a massive infiltration of neutrophil granulocytes into the affected mucosa, manifested by an increase in stool granulocytes. When stimulated with pro-inflammatory cytokines (eg, IL-1 $\beta$, TNF- $\alpha$, IL-6) or infected with microbial pathogens, intestinal epithelial cells secrete chemokines ${ }^{32}$ (eg, IL-8, MCP-1, MIP-1), directing migration and activation of neutrophils and mononuclear phagocytes from the capillaries of the intestinal villi into the injured tissue. The macrophagederived inflammatory cytokines TNF- $\alpha$, IL- $1 \beta$, IFN $-\gamma$ and IL-6 play a pivotal role in the induction and amplification of the inflammatory cascade in the gut, producing complex networks that activate neutrophils and mononuclear phagocytes in the capillaries to enter the lamina propria and produce tissue damage (see Supplementary Figure 1).

Several studies showed that macrophage-derived cytokines are more abundant than are T-cell cytokines in inflamed mucosa obtained from UC patients ${ }^{33,34}$ with active disease.

In vitro models of activated PBLs have been established in clinical immunology for several decades allowing the situation in acute and chronic inflammation to be mimicked. ${ }^{35-37}$

Specifically activation of PBLs in vitro reproduces the cytokine expression ${ }^{19}$ present in inflamed intestinal mucosa ${ }^{11}$ of patients with chronic intestinal inflammation.

A quantitative analysis of intestinal mucosal mRNA expression in colonic biopsies and PBL from IBDs patients has been previously performed. ${ }^{11}$ This study showed that the expression of the acute phase mediators IL- $1 \beta$, IL- 6 and TNF- $\alpha$ is increased in the mucosa obtained from patients with active disease. Moreover the quantitative relationship between the cytokines observed in vitro mimics that observed in the inflamed mucosa in vivo as IL-6, IL-1 $\beta$, TNF- $\alpha$ and IFN- $\gamma$ are all strongly induced 

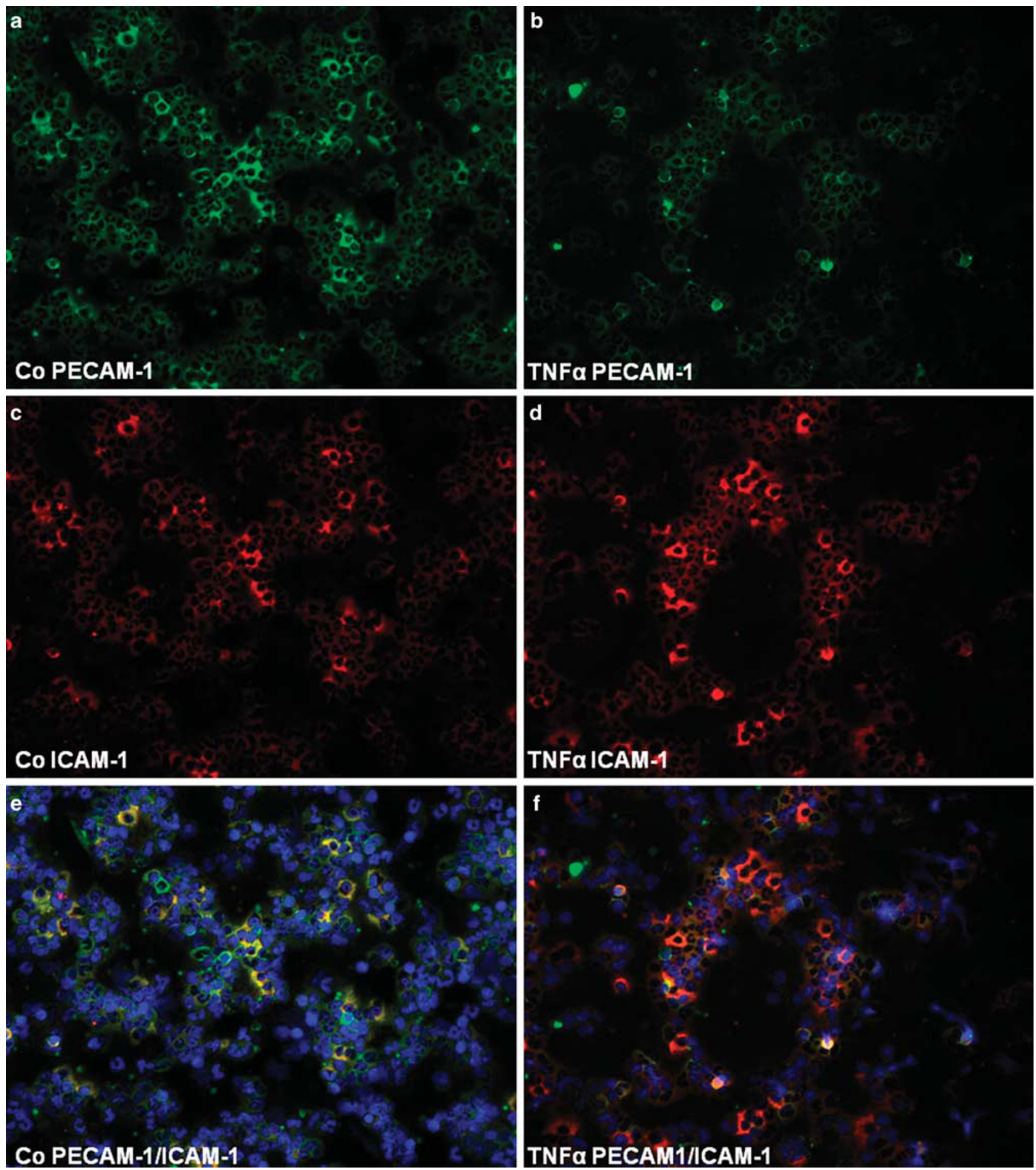

Figure 8 Immunofluorescence staining of in vitro isolated human granulocytes cytospins with monoclonal antibody directed against mouse anti-PECAM-1 (green) and polyclonal antibody against rabbit ICAM-1 (red) followed by fluorescence immunodetection in unstimulated ( $\mathbf{a}=$ control PECAM-1, $\mathbf{c}=$ control ICAM-1, e $=$ double staining control ICAM-1/PECAM-1) and stimulated cells with TNF- $\alpha(\mathbf{b}=$ TNF- $\alpha$ PECAM-1, $\mathbf{d}=$ TNF- $\alpha$ ICAM- 1 , $\mathbf{f}=$ double staining TNF- $\alpha$ ICAM-1/PECAM-1. Original magnification: $\times 200$. Scale bar $=100 \mu \mathrm{m}$.

in in vitro by 'activated' PBLs, as well as in colonic biopsies obtained from patients with acute flares of UC. ${ }^{19}$

The development of the anti-tumor necrosis factor (TNF) antibodies has revolutionized the management of many chronic-inflammatory diseases and is now an approved treatment for CD, UC, juvenile RA, ankylosing spondylitis, psoriatic arthritis and psoriasis ${ }^{38,39}$ However, the mechanisms of their actions are unclear and $\sim 10 \%$ of patients with 
'refractory' or newly diagnosed CD fail to respond to antiTNF treatment. ${ }^{40}$

In normal conditions TNF- $\alpha$ has important roles in the development of the immune system and host protection against infectious pathogens. The altered mucosal immune response, characterized by an increased production of TNF- $\alpha$ by local macrophages or monocytes, is characteristic of intestinal mucosa obtained from individuals with IBD. ${ }^{41}$

Several studies have demonstrated that infliximab exerts its anti-inflammatory effect by downregulation of the proinflammatory cytokines TNF- $\alpha$, IL- 6 , IL- $1 \beta$ and IL- $8 .{ }^{42,43}$

Several families of molecules, including adhesion molecules and chemokines, regulate the influx of inflammatory cells from the blood into sites of inflammation, these molecules represent an interesting target for the treatment of IBD.

As proinflammatory cytokines induce gene expression of several CAMs, the primary goal of the present study was to investigate changes of gene expression of ICAM-1, PECAM-1 and VCAM-1, in in vitro activated human leukocytes and to examine the effect of infliximab on their expression.

The process of leukocyte rolling, adhesion and migration across blood vessels and sinusoids wall (diapedesis) involves various families of chemokines ${ }^{44}$ and cell adhesion molecules, to include selectins, ${ }^{45}$ integrins, ${ }^{46}$ VCAM-1, ICAM- $1,{ }^{47}$ ICAM-2, ${ }^{48}$ junctional adhesion molecules, ${ }^{49}$ VE-cadherin, platelet endothelial cell adhesion molecule-1 (PECAM-1, CD-31) and CD-99..$^{50}$ Although rolling and sticking are supposed to take place by the linking of vascular molecules to ligands expressed on the surface of leukocytes, leukocyte transmigration involves homophilic interactions between inflammatory cell molecules and the adhesion molecules ICAM-1, LFA-1 and ICAM-2.

PECAM-1 belongs to the Ig superfamily of cell adhesion molecules. It has been shown to be vital for the regulation of inflammatory responses, as it activates a variety of pro-inflammatory and anti-inflammatory functions in both leukocytes and endothelial cells. ${ }^{50-53}$ Ligands for PECAM-1 include integrin $\alpha \mathrm{v} \beta 3, \alpha 6 \beta 1$ or CD38. PECAM-1 is also involved in leukocyte migration across the 'second barrier', the subendothelial basal membrane. ${ }^{54}$ Blocking PECAM-1 in mice has been shown to prevent acute inflammation in vivo. ${ }^{55}$ In addition antibody-mediated blocking of PECAM-1 reduces transmigration of monocytes, neutrophils and natural killer cells. ${ }^{56}$ It has been suggested that PECAM-1 guides leukocytes through the endothelium via enhanced expression at endothelial cell junctions through recycling of PECAM-1-rich membrane invaginations at the lateral junctions of endothelial cells. ${ }^{52}$

However the specific role of PECAM-1 during the inflammatory process is controversial. Changes of PECAM-1 gene expression on leukocytes under inflammatory conditions have not been carefully investigated. ${ }^{57}$ It has been suggested that, in response to proinflammatory cytokines that include TNF- $\alpha$, IL- $1 \beta$, IFN- $\gamma$ and endotoxins, PECAM- 1 expression is not transcriptionally upregulated, ${ }^{58}$ but is redistributed away from the intercellular junction of endothelial cells indicating that the spatial location of PECAM-1 has a regulatory role in the processes mediated by PECAM- $1 .{ }^{59}$

PECAM-1 gene expression is decreased in vivo in a rat model of liver damage occurring with an upregulation of TNF- $\alpha$ and IFN- $\gamma$ gene expression, and under in vitro 'inflammatory conditions., ${ }^{22,60}$ In fact, IFN- $\gamma$ as well as TNF- $\alpha$ downregulates PECAM-1 and upregulates ICAM-1 gene expression in macrophages obtained from liver tissue and in endothelial cell cultures.

These results were confirmed in the present study in human granulocytes as ICAM-1 upregulation and PECAM-1 downregulation occurred after treatment with TNF- $\alpha$ and IFN- $\gamma$ at RNA level and after performing immunohistochemical studies. The lack of effect by PHA and LPS on ICAM-1 and PECAM-1 gene expression in granulocytes, other than that observed in PBLs and monocytic cells, can be explained on one side by the almost complete lack of monocytes in the granulocyte culture, having as a consequence a lower amount of cytokines mRNA synthesis in these cells, and on the other side by the strong 'activation' of the granulocyte with a consequent downregulation of PECAM-1 gene expression as shown by the high Ct-values in freshly isolated control granulocytes.

By performing real-time PCR, we could clearly demonstrate that the massive production of acute phase cytokines, which is known to have a striking role in leukocytes activation induced by PHA or LPS in PBLs, cannot be shown in PHA or LPS stimulated granulocytes. TNF- $\alpha$ or IFN- $\gamma$, at the dosage used in the experiments, however, showed the expected effect on ICAM-1 and PECAM-1 gene expression also in granulocytes.

The late increase in TGF- $\beta 1$ gene expression in rat liver seen during the recovery period after $\mathrm{CCl}_{4}$-induced damage. ${ }^{22,60}$ suggested that TGF- $\beta 1$ counteracts the effects of both IFN- $\gamma$ and TNF- $\alpha$ by upregulating PECAM- 1 and downregulating ICAM-1 gene expression.

The principal finding of this study is that PECAM-1 gene expression is downregulated under 'inflammatory' conditions in parallel with an increase in ICAM-1 and VCAM-1expression; ${ }^{61,62}$ PECAM-1 downregulation and ICAM-1 upregulation in activated PBLs were completely suppressed by the anti-TNF- $\alpha$ antibody infliximab. These findings were confirmed by immunofluorescence detection of PECAM-1and ICAM-1-positive cells, which showed a complete recovery of PECAM-1 ${ }^{+}$and a reduction of ICAM-1 ${ }^{+}$ leukocytes and granulocytes after treatment with infliximab, alone or in combination with PHA or LPS. These results suggest that infliximab, by blocking TNF- $\alpha$ and consequently IFN- $\gamma$ activity, may exert its anti-inflammatory effect also through downregulation of PECAM-1 gene expression and upregulation of ICAM-1 and VCAM-1 gene expression not only on the cells of the intestinal mucosa but also in the blood leukocytes. 
The question of the mechanisms by which the anti-TNF- $\alpha$ antibody inhibits IFN- $\gamma$ synthesis and which cellular mechanism is responsible for PECAM-1 recovery during anti-TNF- $\alpha$ treatment was therefore addressed.

Previously it has been shown that IFN- $\gamma$-treatment induces a reduction of PECAM-1 gene expression occurring in parallel with an increase in ICAM-1 expression in isolated sinusoidal endothelial cells and liver tissue macrophages. ${ }^{22}$ In the present work, we could confirm these results showing that PHA-, LPS-induction of TNF- $\alpha$ and IFN- $\gamma$ produced a time-dependent PECAM-1 downregulation and TNF- $\alpha$ sharply upregulated IFN- $\gamma$ gene expression in an in vitro leukocyte model. These results match previous findings reporting that the expression of PECAM-1, in in vitro isolated endothelial cells, drops due to an increase of TNF- $\alpha$ and IFN- $\gamma .{ }^{63}$

Moreover, the results are consistent with the view that infliximab, by blocking soluble TNF- $\alpha$, indirectly inhibits IFN- $\gamma$ gene expression, preventing the downregulation of PECAM-1 and upregulation of ICAM-1 and VCAM-1 gene expression, not only on endothelial cells but also on blood leukocytes, a prerequisite for adhesion and transmigration of inflammatory leukocytes into tissue.

This effect of anti-TNFs in this sequence might contribute to a reduction in the inflammation in patients with IBDs.

The second important finding of the present in vitro experiments is that incubation of PBLs with TGF- $\beta$ induced a time-dependent upregulation of PECAM-1 gene expression. TGF- $\beta$ is a highly pleiotropic cytokine that stimulates most of the processes of wound healing and is considered to be the major profibrotic factor and it promotes angiogenesis both in in vivo and in vitro models. ${ }^{64,65}$

The findings of this investigation may lead to reveal novel therapeutic targets in the treatment of both acute and chronic inflammatory disorders.

Supplementary Information accompanies the paper on the Laboratory Investigation website (http://www.laboratoryinvestigation.org)

\section{ACKNOWLEDGEMENTS}

We are greatly indebted to E Neumann and S Heyroth for their expert technical assistance.

\section{DISCLOSURE/CONFLICT OF INTEREST}

The authors declare no conflict of interest.

1. Eksteen B, Liaskou E, Adams DH. Lymphocyte homing and its role in the pathogenesis of IBD. Inflamm Bowel Dis 2008;14:1298-1312.

2. Lekstrom-Himes JA, Gallin Jl. Immunodeficiency diseases caused by defects in phagocytes. N Engl J Med 2000;343:1703-1714.

3. Nathan C. Neutrophils and immunity: challenges and opportunities. Nat Rev Immunol 2006;6:173-182.

4. McDonald B, Pittman K, Menezes GB, et al. Intravascular danger signals guide neutrophils to sites of sterile inflammation. Science 2010;330: 362-366.

5. Guerrant RL, Araujo V, Soares E, et al. Measurement of fecal lactoferrin as a marker of fecal leukocytes. J Clin Microbiol 1992;30:1238-1242.

6. Woywodt A, Ludwig D, Neustock P, et al. Mucosal cytokine expression, cellular markers and adhesion molecules in inflammatory bowel disease. Eur J Gastroenterol Hepatol 1999;11:267-276.
7. Smiljanovic B, Grun JR, Steinbrich-Zollner M, et al. Defining TNF-alphaand LPS-induced gene signatures in monocytes to unravel the complexity of peripheral blood transcriptomes in health and disease. J Mol Med 2010;88:1065-1079.

8. Shah VO, Ferguson JE, Hunsaker LA, et al. Natural products inhibit LPSinduced activation of pro-inflammatory cytokines in peripheral blood mononuclear cells. Nat Prod Res 2010;24:1177-1188.

9. Batliwalla FM, Baechler EC, Xiao X, et al. Peripheral blood gene expression profiling in rheumatoid arthritis. Genes Immun 2005;6: 388-397.

10. Baechler EC, Batliwalla FM, Karypis G, et al. Interferon-inducible gene expression signature in peripheral blood cells of patients with severe lupus. Proc Natl Acad Sci USA 2003;100:2610-2615.

11. Raddatz D, Bockemuhl M, Ramadori G. Quantitative measurement of cytokine mRNA in inflammatory bowel disease: relation to clinical and endoscopic activity and outcome. Eur J Gastroenterol Hepatol 2005; 17:547-557.

12. Targan SR, Hanauer SB, van Deventer SJ, et al. A short-term study of chimeric monoclonal antibody CA2 to tumor necrosis factor alpha for Crohn's disease. Crohn's Disease CA2 Study Group. N Engl J Med 1997;337:1029-1035.

13. Baert FJ, D'Haens GR, Peeters $M$, et al. Tumor necrosis factor alpha antibody (infliximab) therapy profoundly down-regulates the inflammation in Crohn's ileocolitis. Gastroenterology 1999;116:22-28.

14. Olsen T, Cui G, Goll R, et al. Infliximab therapy decreases the levels of TNF-alpha and IFN-gamma mRNA in colonic mucosa of ulcerative colitis. Scand J Gastroenterol 2009;44:727-735.

15. Scallon B, Cai A, Solowski N, et al. Binding and functional comparisons of two types of tumor necrosis factor antagonists. J Pharmacol Exp Ther 2002;301:418-426.

16. Charles P, Elliott MJ, Davis D, et al. Regulation of cytokines, cytokine inhibitors, and acute-phase proteins following anti-TNF-alpha therapy in rheumatoid arthritis. J Immunol 1999;163:1521-1528.

17. Ohshima S, Saeki Y, Mima T, et al. Long-term follow-up of the changes in circulating cytokines, soluble cytokine receptors, and white blood cell subset counts in patients with rheumatoid arthritis (RA) after monoclonal anti-TNF alpha antibody therapy. J Clin Immunol 1999;19:305-313.

18. Agnholt J, Dahlerup JF, Kaltoft K. The effect of etanercept and infliximab on the production of tumour necrosis factor alpha, interferon-gamma and GM-CSF in in vivo activated intestinal T lymphocyte cultures. Cytokine 2003;23:76-85.

19. Moriconi F, Raddatz D, Ho NA, et al. Quantitative gene expression of cytokines in peripheral blood leukocytes stimulated in vitro: modulation by the anti-tumor nerosis factor-alpha antibody infliximab and comparison with the mucosal cytokine expression in patients with ulcerative colitis. Transl Res 2007;150:223-232.

20. Lugering $A$, Schmidt $M$, Lugering $N$, et al. Infliximab induces apoptosis in monocytes from patients with chronic active Crohn's disease by using a caspase-dependent pathway. Gastroenterology 2001;121: 1145-1157.

21. Ringheanu M, Daum F, Markowitz J, et al. Effects of infliximab on apoptosis and reverse signaling of monocytes from healthy individuals and patients with Crohn's disease. Inflamm Bowel Dis 2004;10: 801-810.

22. Neubauer $K$, Lindhorst $A$, Tron $K$, et al. Decrease of PECAM-1-geneexpression induced by proinflammatory cytokines IFN-gamma and IFN-alpha is reversed by TGF-beta in sinusoidal endothelial cells and hepatic mononuclear phagocytes. BMC Physiol 2008;8:9.

23. Neubauer K, Ritzel A, Saile B, et al. Decrease of platelet-endothelial cell adhesion molecule 1-gene-expression in inflammatory cells and in endothelial cells in the rat liver following $\mathrm{CCl}(4)$-administration and in vitro after treatment with TNFalpha. Immunol Lett 2000;74:153-164.

24. Boyum A. Isolation of mononuclear cells and granulocytes from human blood. Isolation of monuclear cells by one centrifugation, and of granulocytes by combining centrifugation and sedimentation at $1 \mathrm{~g}$. Scand J Clin Lab Invest Suppl 1968;97:77-89.

25. Dudas J, Mansuroglu T, Batusic $\mathrm{D}$, et al. Thy-1 is an in vivo and in vitro marker of liver myofibroblasts. Cell Tissue Res 2007;329:503-514.

26. Malik IA, Moriconi F, Sheikh N, et al. Single-dose gamma-irradiation induces up-regulation of chemokine gene expression and recruitment of granulocytes into the portal area but not into other regions of rat hepatic tissue. Am J Pathol 2010;176:1801-1815. 
27. Herbst $\mathrm{H}$, Heinrichs $\mathrm{O}$, Schuppan $\mathrm{D}$, et al. Temporal and spatial patterns of transin/stromelysin RNA expression following toxic injury in rat liver. Virchows Arch B Cell Pathol Incl Mol Pathol 1991;60: 295-300.

28. Towbin H, Staehelin T, Gordon J. Electrophoretic transfer of proteins from polyacrylamide gels to nitrocellulose sheets: procedure and some applications. Proc Natl Acad Sci USA 1979;76:4350-4354.

29. Sartor RB. Innate immunity in the pathogenesis and therapy of IBD. J Gastroenterol 2003;38(Suppl 15):43-47.

30. Smith PD, Ochsenbauer-Jambor C, Smythies LE. Intestinal macrophages: unique effector cells of the innate immune system. Immunol Rev 2005;206:149-159.

31. Smythies $L E$, Sellers $M$, Clements $R H$, et al. Human intestinal macrophages display profound inflammatory anergy despite avid phagocytic and bacteriocidal activity. J Clin Invest 2005;115:66-75.

32. Yeruva S, Ramadori G, Raddatz D. NF-kappaB-dependent synergistic regulation of CXCL10 gene expression by IL-1 beta and IFN-gamma in human intestinal epithelial cell lines. Int J Colorectal Dis 2008;23: 305-317.

33. Atreya R, Neurath MF. Involvement of IL- 6 in the pathogenesis of inflammatory bowel disease and colon cancer. Clin Rev Allergy Immunol 2005;28:187-196.

34. Hosokawa T, Kusugami K, Ina K, et al. Interleukin-6 and soluble interleukin- 6 receptor in the colonic mucosa of inflammatory bowe disease. J Gastroenterol Hepatol 1999;14:987-996.

35. Kooijman R, Devos S, Hooghe-Peters E. Inhibition of in vitro cytokine production by human peripheral blood mononuclear cells treated with xenobiotics: implications for the prediction of general toxicity and immunotoxicity. Toxicol In Vitro 2010;24:1782-1789.

36. Yaqub S, Solhaug V, Vang T, et al. A human whole blood model of LPSmediated suppression of $\mathrm{T}$ cell activation. Med Sci Monit 2003;9:BR120-BR126.

37. Klotz L, Schmidt M, Giese $T$, et al. Proinflammatory stimulation and pioglitazone treatment regulate peroxisome proliferator-activated receptor gamma levels in peripheral blood mononuclear cells from healthy controls and multiple sclerosis patients. J Immunol 2005;175:4948-4955.

38. Wong $\mathrm{M}$, Ziring $\mathrm{D}$, Korin $\mathrm{Y}$, et al. TNFalpha blockade in human diseases: mechanisms and future directions. Clin Immunol 2008;126:121-136.

39. Lichtenstein GR, Bala M, Han C, et al. Infliximab improves quality of life in patients with Crohn's disease. Inflamm Bowel Dis 2002;8:237-243.

40. Schnitzler $F$, Fidder $H$, Ferrante $M$, et al. Long-term outcome of treatment with infliximab in 614 patients with Crohn's disease: results from a single-centre cohort. Gut 2009;58:492-500.

41. Cooper HS, Murthy S, Kido K, et al. Dysplasia and cancer in the dextran sulfate sodium mouse colitis model. Relevance to colitis-associated neoplasia in the human: a study of histopathology, B-catenin and p53 expression and the role of inflammation. Carcinogenesis 2000;21:757-768.

42. Scallon BJ, Moore MA, Trinh $\mathrm{H}$, et al. Chimeric anti-TNF-alpha monoclonal antibody CA2 binds recombinant transmembrane TNF-alpha and activates immune effector functions. Cytokine 1995;7:251-259.

43. Brennan FM, Chantry D, Jackson A, et al. Inhibitory effect of TNF alpha antibodies on synovial cell interleukin-1 production in rheumatoid arthritis. Lancet 1989;2:244-247.

44. Wasmuth $\mathrm{HE}$, Tacke $\mathrm{F}$, Trautwein $\mathrm{C}$. Chemokines in liver inflammation and fibrosis. Semin Liver Dis 2010;30:215-225.

45. Kansas GS. Selectins and their ligands: current concepts and controversies. Blood 1996;88:3259-3287.

46. Dangerfield J, Larbi KY, Huang MT, et al. PECAM-1 (CD31) homophilic interaction up-regulates alpha6beta1 on transmigrated neutrophils in vivo and plays a functional role in the ability of alpha6 integrins to mediate leukocyte migration through the perivascular basement membrane. J Exp Med 2002;196:1201-1211.

47. Sans M, Panes J, Ardite E, et al. VCAM-1 and ICAM-1 mediate leukocyteendothelial cell adhesion in rat experimental colitis. Gastroenterology 1999;116:874-883.

48. Huang MT, Larbi KY, Scheiermann C, et al. ICAM-2 mediates neutrophil transmigration in vivo: evidence for stimulus specificity and a role in PECAM-1-independent transmigration. Blood 2006;107:4721-4727.

49. Su WH, Chen HI, Jen CJ. Differential movements of VE-cadherin and PECAM-1 during transmigration of polymorphonuclear leukocytes through human umbilical vein endothelium. Blood 2002;100: 3597-3603.

50. Schenkel AR, Mamdouh Z, Chen X, et al. CD99 plays a major role in the migration of monocytes through endothelial junctions. Nat Immunol 2002;3:143-150.

51. Jackson DE. The unfolding tale of PECAM-1. FEBS Lett 2003;540:7-14.

52. Mamdouh $Z$, Chen X, Pierini LM, et al. Targeted recycling of PECAM from endothelial surface-connected compartments during diapedesis. Nature 2003;421:748-753.

53. Privratsky JR, Newman DK, Newman PJ. PECAM-1: conflicts of interest in inflammation. Life Sci 2010;87:69-82.

54. Thompson RD, Noble KE, Larbi KY, et al. Platelet-endothelial cell adhesion molecule-1 (PECAM-1)-deficient mice demonstrate a transient and cytokine-specific role for PECAM-1 in leukocyte migration through the perivascular basement membrane. Blood 2001:97:1854-1860.

55. Bogen S, Pak J, Garifallou M, et al. Monoclonal antibody to murine PECAM-1 (CD31) blocks acute inflammation in vivo. J Exp Med 1994;179:1059-1064.

56. Newman PJ. The biology of PECAM-1. J Clin Invest 1997:100:S25-S29.

57. Vestweber D. Adhesion and signaling molecules controlling the transmigration of leukocytes through endothelium. Immunol Rev 2007;218:178-196.

58. DeLisser HM, Newman PJ, Albelda SM. Molecular and functional aspects of PECAM-1/CD31. Immunol Today 1994;15:490-495.

59. Romer LH, McLean NV, Yan HC, et al. IFN-gamma and TNF-alpha induce redistribution of PECAM-1 (CD31) on human endothelial cells. $\mathrm{J}$ Immunol 1995;154:6582-6592.

60. Neubauer K, Ritzel A, Saile B, et al. Decrease of platelet-endothelial cell adhesion molecule 1-gene-expression in inflammatory cells and in endothelial cells in the rat liver following $\mathrm{CCl}(4)$ administration and in vitro after treatment with TNFalpha. Immunol Lett 2000:74:153-164

61. Stockinger H, Gadd SJ, Eher R, et al. Molecular characterization and functional analysis of the leukocyte surface protein CD31. J Immunol 1990;145:3889-3897.

62. Zehnder JL, Hirai K, Shatsky M, et al. The cell adhesion molecule CD31 is phosphorylated after cell activation. Down-regulation of CD31 in activated T lymphocytes. J Biol Chem 1992;267:5243-5249.

63. Stewart RJ, Kashour TS, Marsden PA. Vascular endothelial platelet endothelial adhesion molecule-1 (PECAM-1) expression is decreased by TNF-alpha and IFN-gamma. Evidence for cytokine-induced destabilization of messenger ribonucleic acid transcripts in bovine endothelial cells. J Immunol 1996;156:1221-1228.

64. Ruiz-Ortega $M$, Rodriguez-Vita J, Sanchez-Lopez $E$, et al. TGF-beta signaling in vascular fibrosis. Cardiovasc Res 2007;74: 196-206.

65. Teraoka H, Sawada T, Nishihara T, et al. Enhanced VEGF production and decreased immunogenicity induced by TGF-beta 1 promote liver metastasis of pancreatic cancer. Br J Cancer 2001;85:612-617. 